ISSN : 2252-3839 (Print)

ISSN : 2549-2403 (On Line)

DOI : 10.28989/compiler.v8i2.532

http://ejournals.stta.ac.id/index.php/compiler/

\title{
DESIGNING A MANAGEMENT INFORMATION SYSTEM PROTOTYPE FOR A PHILANTHROPIC ORGANIZATION: A CASE STUDY OF YAAB ORBIT YOGYA
} Sita Dewi Kusumaningrum ${ }^{1)}$, Hari Setiaji ${ }^{2)}$,Wildan Maulana ${ }^{3)}$

Departement ${ }^{1}$ Management, ${ }^{2,3}$ Informatics

Faculty ${ }^{1}$ Economics, ${ }^{2,3}$ Industrial Technology

Universitas Islam Indonesia

Jalan Kaliurang Km 14, Ngemplak, Sleman, DI Yogyakarta, 55584

Email: ${ }^{1}$ sita.kusumaningrum@uii.ac.id, ${ }^{2}$ hari.setiaji@uii.ac.id,

314523300@students.uii.ac.id

\begin{abstract}
Modern philanthropic organizations are responsible for the use of social resources. However, some of them are facing several managerial issues, including inadequate database management and lack of accountability. To support the documenting process and to improve the management of funds, these organizations need a computerbased information management. This qualitative action research using prototyping method aimed at designing a management information system for a philanthropic organization which focus on providing education access for disadvantaged students in Yogyakarta. The process of designing management information system in the case study was applying a prototyping method since not every organization including a philanthropic organization could explicitly define the information needed to support their business process. This prototype was designed based on organization's requirements so that users can obtain any information needed easily. The management information system prototype could provide assistance for a philanthropic organization in managing and documenting all activities in the organization.
\end{abstract}

Keywords: philanthropic organization, prototyping method, management information system

\section{Introduction}

To date, philanthropic organizations are growing rapidly in Indonesia. As nonprofit organizations, many philanthropic organizations are established in Indonesia in the forms of foundations, associations, and communities. They are often managed based on family, company, religion, and community organization. The rapid growing of philanthropic organizations in Indonesia is in line with the fact that British organization Charities Aid Foundation (CAF) through the 2018 World Giving Index has announced the position of Indonesia as the world's most generous countries in terms of donating money, helping a stranger and volunteering in the past month when the survey was conducted. In the previous year, Indonesia was on the second position [1].

Generally, philanthropy can be defined as voluntary actions for the public benefit. There are two characters of philanthropy, namely traditional philanthropy and modern philanthropy [6]. The traditional philanthropy is more on individual charity, while modern philanthropy is more on social charity and resources mobility to make social changes through community organizing, advocacy and public education. Based on its nature, modern philanthropy requires more social responsibility than traditional philanthropy. The modern philanthropic organizations in Indonesia today are such as Dompet Dhuafa, 
Yayasan TiFA, Rumah Zakat, Aksi Cepat Tanggap (ACT), Badan Amil Zakat Nasional (BAZNAS), and so on. They are mostly non-profit and independent organizations which intended to contribute more for the social equity and sustainable development of Indonesia.

Despite the noble purposes of philanthropic organizations in Indonesia, some of them are dealing with several management issues. First, some philanthropic organizations are still managed based on trust. Second, the organizer is voluntary. Third, there are uncertain source of funds. Fourth, some philanthropic organization are not supported by sufficient management information system [3].

Yayasan Amal Abadi Beasiswa- Orang Tua Bimbing Terpadu (YAAB Orbit) is a modern philanthropic organization located in Yogyakarta which provide educational access and scholarship for university as well as high school students. It has been initiated since 1992 by the Indonesian Association of Muslim Intellectuals (ICMI). Every year, there are approximately 40-50 students who receive scholarship (scholarship recipients) from YAAB Orbit and become "anak bimbing" or mentored youth. Besides allocates some financial aids, this organization also carries out workshops and trainings regularly to improve the characters and soft-skills of the mentored youth.

Although YAAB Orbit has been organized for more than 20 years, it is now still facing several managerial issues regarding:

1) Financial resource management. This organization requires more funding resource. The fundraising activities is not optimal due to inadequate marketing tools, such as no suitable website, inactive social media, and minimum promotion activities.

2) Performance management. It includes the responsibility for the use of fund and the fund management. The documenting process is important to evaluate and report the organization performance. To date this organization already has a lot of data ranging from stakeholders data to activities and financial data. However, this organization still do not have a good documenting system. The documenting process is still manually. This organization also do not have a good reporting system on activities as well as the use of financial resource.

3) Human resource management. The human resource and stakeholders in this organization covers the organizer, the scholarship recipients/mentored youth, and the donors. The organizer is voluntary and each of the organizer also have their other professional responsibility. Therefore, they cannot focus on the organization mission as well as maintain the other stakeholders.

In order to comply with its nature as a modern philanthropic organization, YAAB Orbit should improve the management process. One solution to be implemented is by designing a computer-based information technology. However, based on observation, YAAB Orbit could not identify the system needs for information technology. Therefore, the prototyping method was chosen. The prototyping method has been used in the development of information system of many organizations in Indonesia including higher education sector [4], tourism [12], and disaster management [13] due to its pleasant implementation. To provide other empirical case study in the implementation of prototyping method, this paper discuss the process of designing YAAB Orbit information management system as a philanthropic organization.

\section{Research Method}

This is an action research based on a community service activity which apply the prototyping method in the system development. This method can help a system developer to gather required information from the interaction between the user and the prototype 
[2][4][5][9]. In the end, this method will produce a system that will be in accordance with user need and provide an appropriate understanding [10][11]. As also become a preliminary version of the system, prototype has several advantages and benefits such as [8][9][10]:

1) Prototyping serves a real system in a visual replica

2) Prototyping makes it easier for developers to make corrections and changes to the product being developed based on the users feed back

3) Prototyping saves resources and time in producing products better and more effective for users

4) Prototyping can be applied to the development of large and small system

The prototyping method starts with needs collection, involving system developers and users to determine the goals, functions, and operational needs of the system [9]. Further, the steps of prototyping in this research are as follows [10]:

1) Collecting needs;

2) Designing process;

3) Building a prototype; and

4) Evaluating the system.

The design focuses on the representation of software aspects from an user perspectives; this includes input, process and output formats. Quick design are leading to prototype development, prototypes are evaluated by users and the design analyst section and is used to adjust device requirements software that will be developed. Prototype are arranged to meet the needs users, and at that moment the developer understand more clearly and details of what needs to be done.

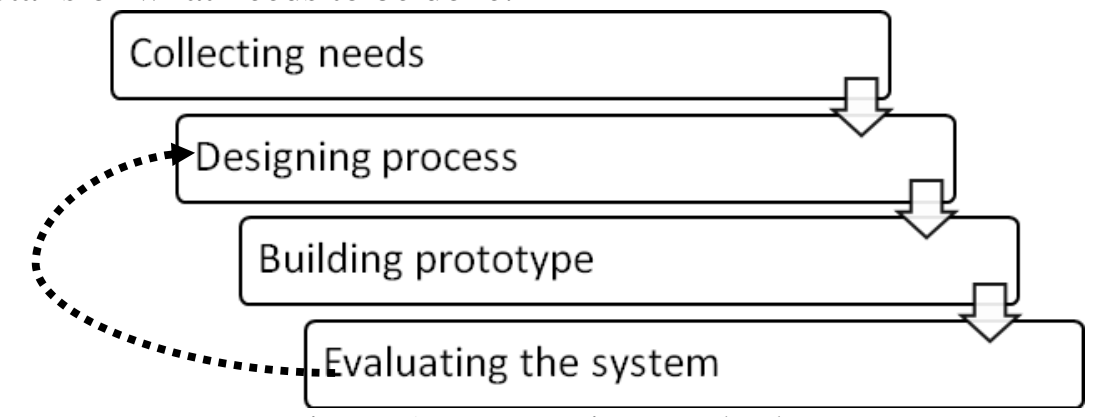

Figure 1. Prototyping Method

After all the four steps of prototyping are accomplished, the final step is the manufacture or design of the actual system

\section{Findings and Results}

\subsection{Problem Identification and Needs Collection in the Philanthropic Organization}

This phase aims at analyzing the current components of information that are already available in the organization system. It comprises the input, the process, the output, the protection, and the control. Further, this phase is intended to identify problems and system specific needs. Several interviews with organization stakeholders were carried out. The stakeholders of YAAB Orbit consists of 1) Core organizer (Pengurus Inti); 2) Mentored Youth (Anak Bimbing); 3) Organizer from Mentored Youth (Pengurus dari Anak Bimbing); and 4) Adoptive Parents (Wali Angkat). All information in the interviews were recorded, documented, and collected. The identification of problems consisted of three activities, namely 1) pre-observation identification and system analysis; 2) observation and interviews; and 3) post-observation identification and system analysis. 
From the observation and interviews to the organization stakeholders, it was found that the database management were still in the form of hardcopy. The documenting process was still manually using books or separate files on computer. Therefore, it was difficult to recall the data quickly. Based on the identification there were several essential Business Process, i.e:

1) Registration of Mentored Youth Candidate

2) Selection of Mentored Youth Candidate

3) Registration of New Mentored Youth

4) Submission of New Scholarship Application for Existing Youth Mentored

5) Academic Report, Achievements, and Activities

6) Training for Mentored Youth and Scholarship Awarding

7) Finding and Registering Adoptive Parents and Donors

8) Receipt of Payments from Adoptive Parents and Donors

\subsection{System Design and Prototyping Process}

In this phase, the design of management information system prototype was developed based on problem and needs identification. There were five modules as a solution from the business analysis as described in Table 1 below.

Table 1. Modules

\begin{tabular}{|c|c|c|}
\hline No & Modules & Needs of Information \\
\hline 1 & Registration Module & $\begin{array}{l}\text { - Organizing registration } \\
\text { - Presenting scholarship applicant } \\
\text { database and applicant documents } \\
\text { requirements }\end{array}$ \\
\hline 2 & Mentored Youth Management Module & $\begin{array}{l}\text { - Presenting the database of Mentored } \\
\text { Youth, the status of Mentored Youth } \\
\text { and data manipulation by organizer }\end{array}$ \\
\hline 3 & $\begin{array}{l}\text { Mentored Youth Report Management } \\
\text { Module }\end{array}$ & $\begin{array}{l}\text { - Reporting management for } \\
\text { Administrator } \\
\text { - Providing reporting site for Mentored } \\
\text { Youth } \\
\text { - Providing academic result and } \\
\text { achievement recapitulation of the } \\
\text { Mentored Youth }\end{array}$ \\
\hline 4 & Adoptive Parents Module & $\begin{array}{l}\text { - Organizing registration, } \\
\text { - Presenting database of Adoptive Parents } \\
\text { applicant and applicant documents } \\
\text { requirements }\end{array}$ \\
\hline 5 & User Management Module & $\begin{array}{l}\text { - Managing the User, adding, organizing, } \\
\text { and changing the status of organizer } \\
\text { user }\end{array}$ \\
\hline
\end{tabular}

The researchers, programmer, and users were working together and maintain cooperation in the process of developing management information system prototype. In order to fulfill the required needs, the prototype should be arranged based on the interaction between analyzer and user [7]. During the development process, users provided inputs and suggestions to improve the system. 
The development of management information system prototype in this case was using MySQL software tool with the interface of PHPMyadmin. Both MySQL and PHPMyadmin are mutual support tools in the web program development. The use of MySQL and PHPMyadmin can facilitate the creation of application for free and stable. The technology of web enable the stakeholders to access and sharing information without special software installed to computer. The web based management information system creates new channel of interactive communication between a philanthropic organization and its stakeholders. Further, the roles of actors/stakeholders in this system which then described in the use diagram were as follows:

1) Core organizer: The core organizer possesses full control to the database system. This user also plays role as administrator.

2) Mentored Youth : This actor only can access to the mentored youth dashboard.

3) Adoptive Parents : This actor only can access to the adopted parents dashboard.

4) Regular User : This actor only can access to registration menu and main website Meanwhile, the design of database is depicted in Figure 1 as follows.
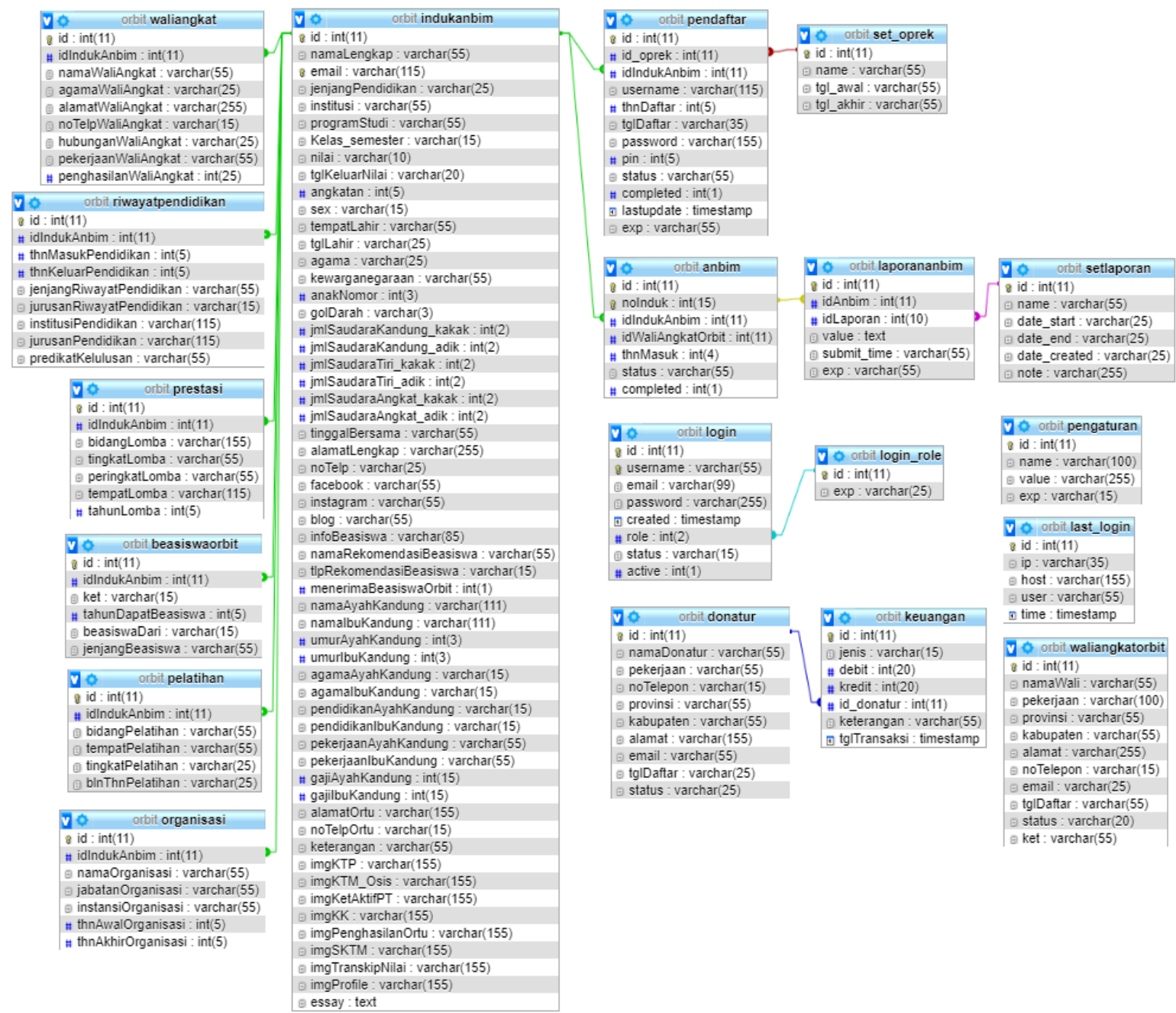

Figure 2. Database Design

The next phase was improving the system based on prototyping evaluation. In this phase, the developer create sprint backlogs consisted of the list of system development and its time line. This activities was accomplished in 36 working days divided into 5 sprints. They are presented in Table 2 to Table 6 . 
Table 2. Iteration 1

\begin{tabular}{|c|c|c|c|c|c|c|c|c|c|c|c|c|}
\hline & & \multicolumn{11}{|c|}{ Day in Sprint } \\
\hline \multicolumn{2}{|c|}{ Iteration 1 - Registration Module } & 1 & 2 & 3 & 4 & 5 & 6 & & & 8 & 9 & 10 \\
\hline 1.1 & Registration display - main page & & & & & & & & & & & \\
\hline 1.2 & Registration display - registration dashboard & & & & & & & & & & & \\
\hline 1.3 & Registration display - registration form & & & & & & & & & & & \\
\hline 1.4 & $\begin{array}{l}\text { Administrator display - registration } \\
\text { management page }\end{array}$ & & & & & & & & & & & \\
\hline 1.5 & Registration module - registration of registrant & & & & & & & & & & & \\
\hline 1.6 & $\begin{array}{l}\text { Registration module - registration management } \\
\text { (administrator) }\end{array}$ & & & & & & & & & & & \\
\hline & Test & & & & & & & & & & & \\
\hline
\end{tabular}

Table 3. Iteration 2

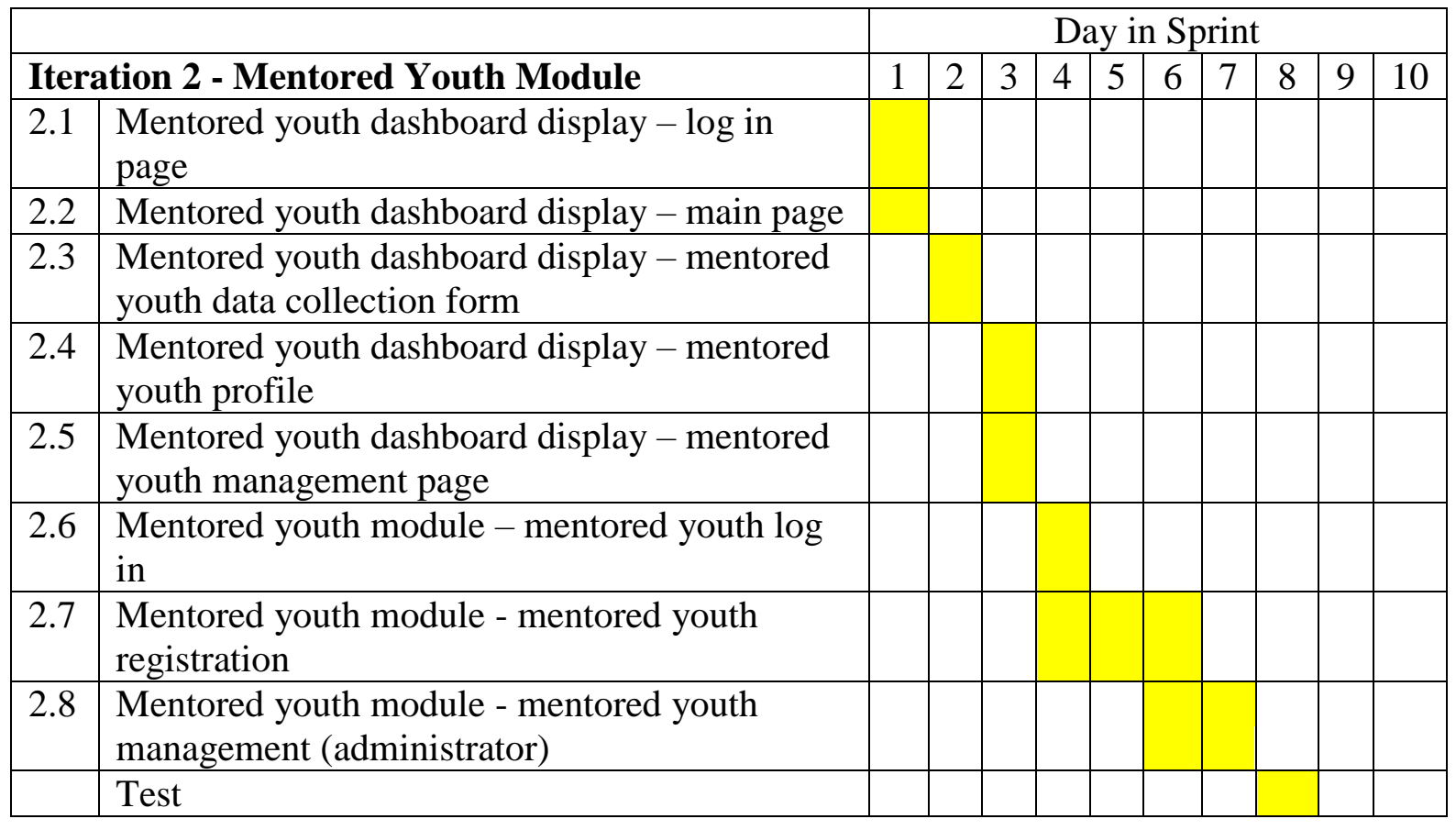

Table 4. Iteration 3

\begin{tabular}{|l|l|l|l|l|l|l|l|l|l|l|l|}
\hline \multicolumn{2}{|l|}{} & \multicolumn{7}{|c|}{ Day in Sprint } \\
\hline $\begin{array}{l}\text { Iteration 3 - Mentored Youth Report } \\
\text { Management Module }\end{array}$ & 1 & 2 & 3 & 4 & 5 & 6 & 7 & 8 & 9 & 10 \\
\hline 3.1 & $\begin{array}{l}\text { Administrator display -mentored youth report } \\
\text { feature page }\end{array}$ & & & & & & & & \\
\hline 3.2 & $\begin{array}{l}\text { Mentored youth dashboard display - report } \\
\text { collection display }\end{array}$ & & & & & & & & & & \\
\hline 3.3 & $\begin{array}{l}\text { Mentored youth report module - report } \\
\text { management (administrator) } \\
\text { collection (mentored youth dashboard) }\end{array}$ & & & & & & & & & \\
\hline & Test & & & & & & & & & & \\
\hline
\end{tabular}


Table 5. Iteration 4

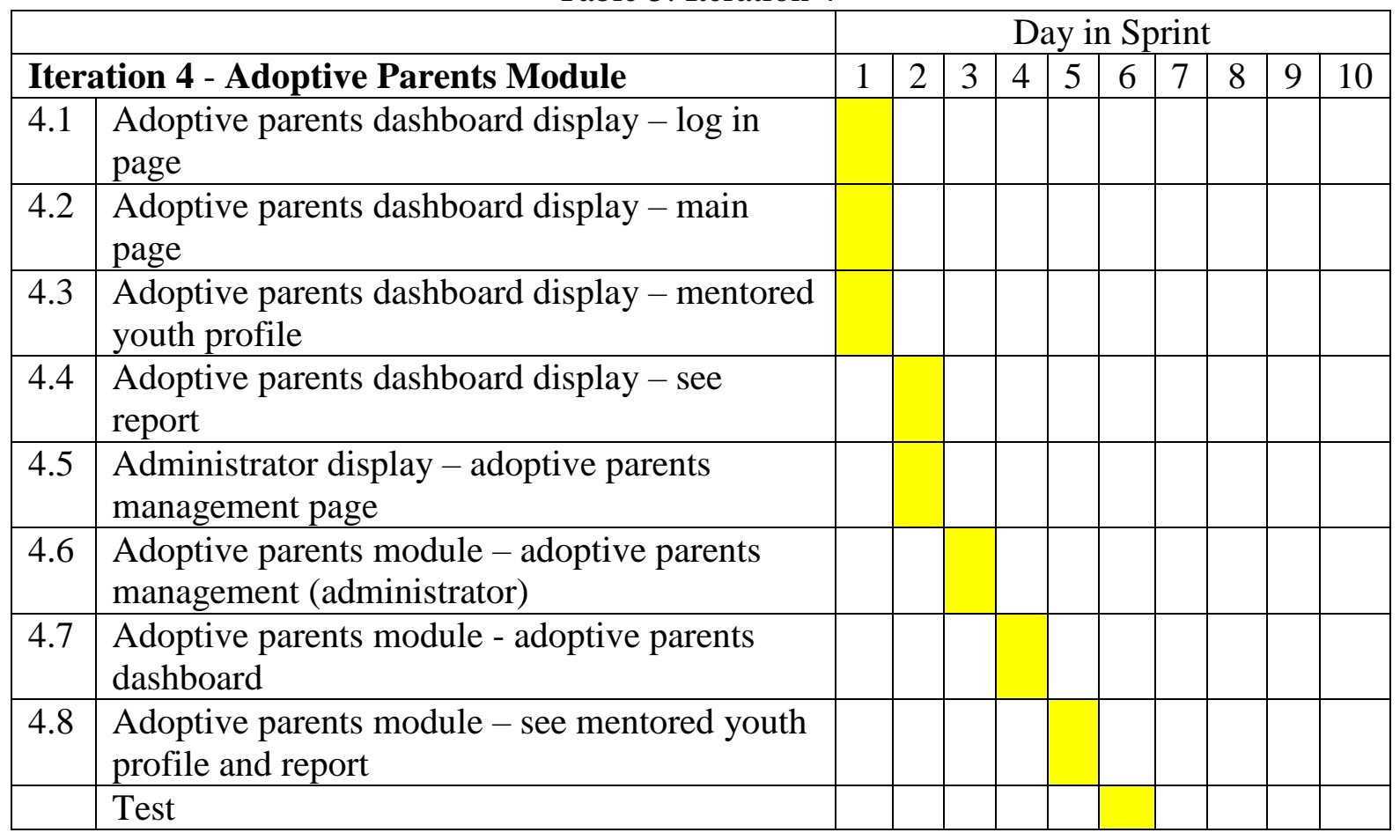

Table 6. Iteration 5

\begin{tabular}{|l|l|l|l|l|l|l|l|l|l|l|l|}
\hline \multicolumn{2}{|l|}{} & \multicolumn{7}{|c|}{ Day in Sprint } \\
\hline $\begin{array}{l}\text { Iteration 5 - User/Organizer Management } \\
\text { Module }\end{array}$ & 1 & 2 & 3 & 4 & 5 & 6 & 7 & 8 & 9 & 10 \\
\hline 5.1 & $\begin{array}{l}\text { Administrator display - organizer management } \\
\text { page }\end{array}$ & & & & & & & & & \\
\hline 5.2 & Organizer Module - organizer management & & & & & & & & & & \\
\hline & Test & & & & & & & & & & \\
\hline
\end{tabular}

\subsection{Result and System Evaluation}

This part explain about the implementation of system with three categories of user whose features have been defined in the analysis phase (Table 1. Module). The final result of system used web platform so that users are easy to access the system anytime and from anywhere (Figure 2). 


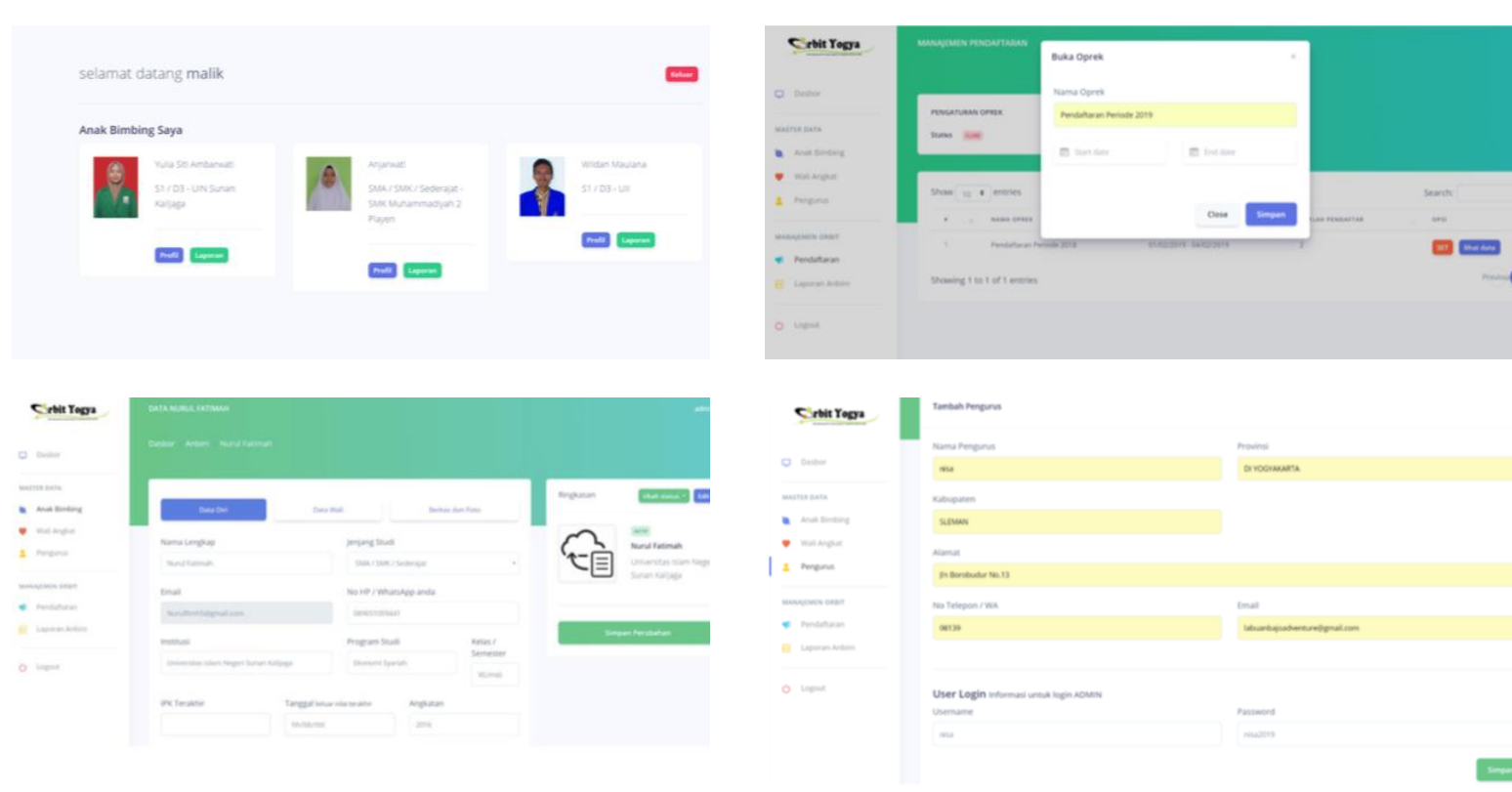

Figure 3. YAAB Orbit Management System Interface

In the next step, the system testing was applied to the stakeholders of YAAB Orbit. Based on this testing, some troubles will be easily to identified. This system testing consisted of two activities:

1) Alfa Version Testing Process. This process was performed individually by the developer based on the flow of scenario. The findings were recorded for the next improvement. The item tested is presented in Table 7.

Table 7. Item Tested in Alfa Version Testing Process

\begin{tabular}{|c|l|c|}
\hline No & \multicolumn{1}{|c|}{ Test Item } & Information \\
\hline 1 & Administrator can log in to administrator dashboard & valid \\
\hline \multicolumn{2}{|l|}{ Registration Module } & valid \\
\hline 2 & Administrator can set registration & valid \\
\hline 3 & Registrant can register & valid \\
\hline 4 & Registrant receive a registration confirmation email & valid \\
\hline 5 & Registrant can fill a form & valid \\
\hline 6 & Registrant can submit the form & valid \\
\hline 7 & Administrator can change the registration status & valid \\
\hline 8 & Registrant can see changes on the registration status & valid \\
\hline 9 & Selected registrant can do re-registration in administrator dashboard & valid \\
\hline 10 & Administrator can see the registrant & valid \\
\hline Mentored Youth Management Module & valid \\
\hline 11 & Administrator can see the mentored youth data & valid \\
\hline 12 & Administrator can remove the mentored youth data & valid \\
\hline 13 & Administrator can open mentored youth data collection & valid \\
\hline 14 & Mentored youth can fill new mentored youth data collection & valid \\
\hline 15 & Mentored youth can log in to mentored youth dashboard & valid \\
\hline 16 & Mentored youth can change the profile & valid \\
\hline 17 & Mentored youth can create new password & \\
\hline 18 & $\begin{array}{l}\text { Administrator can verify data of mentored youth who has just } \\
\text { registered }\end{array}$ & \\
\hline
\end{tabular}




\begin{tabular}{|c|l|c|}
\hline \multicolumn{2}{|l|}{ Mentored Youth Report Management Module } & valid \\
\hline 19 & Administrator can add the report assignment & valid \\
\hline 20 & Administrator can see the report of mentored youth & valid \\
\hline 21 & Administrator can change the report assignment & valid \\
\hline 22 & Administrator see the data of those who submit report & valid \\
\hline 23 & Mentored youth can submit report & valid \\
\hline 24 & Mentored youth can change report & valid \\
\hline Adoptive Parents Module & valid \\
\hline 25 & Administrator can add the data of adoptive parents & valid \\
\hline 26 & Administrator can change the data of adoptive parents & valid \\
\hline 27 & Administrator can remove the data of adoptive parents & valid \\
\hline 28 & Administrator can pair the mentored youth to the adoptive parents & valid \\
\hline 29 & Adoptive parents can log in to their dashboard & valid \\
\hline 30 & Adoptive parents can see the profile of their mentored youth & \\
\hline 31 & Adoptive parents can see the report of their mentored youth & valid \\
\hline User/Organizer Management Module & valid \\
\hline 32 & Administrator can add the data of organizer & valid \\
\hline 33 & Administrator can change the data of organizer \\
\hline 34 & Administrator can remove the data of organizer &
\end{tabular}

2) Beta Version Testing Process. This process was accomplished by all stakeholders (the organizer and mentored youth). The testing process in each iteration provided feedbacks for the developer to improve the system.

\section{Conclusion}

After iterating 5 times to the user, there are 34 valid business process items which are divided into 5 main system modules. The formation of new iterations obtained feedback that results from the confirmation process to the user of the design based on preliminary analysis. Feedback is given by the core organizer and the daily organizer, all feedback is recorded and transformed into a record of improvements or new business processes.

This management information system could facilitate a modern philanthropic organization such as YAAB ORBIT to be more accountable and be able to manage database in more effective and efficient way. The nature of organization in which the organizer do not have leisure time to deal with documenting process will be assisted by this program. The prototyping method become solution in the program development and the right choice to meet the organization needs. Further, the database information system could provide easy access of information for each stakeholders through the developed five modules. For the core organizer, this database information system would assist the management of organization in controlling the organization activities and to be more accountable. In addition, by this database system, YAAB Orbit would be able to professionally managed and this will open more opportunity for fundraising. For the Mentored Youth, this database information would assist them to be more organized and discipline in fulfilling their responsibility. For the adoptive parents, they would be more save and be able to put more trust to the philanthropic organization since they can easily check and control the organization activities. 


\section{References}

[1] Welcome to the 'most generous country' in the world: Indonesia, online: https://www.thejakartapost.com/news/2018/11/02/welcome-to-the-most-generouscountry-in-the-world-indonesia.html. Accessed 8 September 2019.

[2] Baskerville, R.L. (1999). Investigating Information Systems with Action Research. Communication of the Association for Information Systems, 2(19).

[3] Anam, A.K., Ridho, M., \& Rohman, F. (2017). Implementasi Sistem Informasi Yayasan (SIYAP) terhadap Kualitas Tata Kelola Keuangan Yayasan Pendidikan Islam di Jepara. Jurnal ABDIMAS Unmer Malang, 2(2).

[4] Gunarti, R., Nugroho, E., \& Sanjaya, G.Y. (2016). Pengembangan Prototype Sistem Informasi Customer Relationship Management di STIKES Husada Borneo Banjarbaru. Journal of Information Systems for Public Health, 1(2).

[5] Harrudhy, B. D. P. (2018). Desain Sistem Informasi Pemesanan Benih Dan Jamur Berbasis Web. JISKA (Jurnal Informatika Sunan Kalijaga), 3(1), 47-57.

[6] Jusuf, C. (2007). Filantropi Modern untuk Pembangunan Sosial. Jurnal Penelitian dan Pengembangan Kesejahteraan Sosial, 2(01), 74-80.

[7] Kendall, K.E., \& Kendall, J.E. (2011). System Analysis and Design. $8^{\text {th }}$ Edition. Prentice Hall, New Jersey.

[8] O'brien, J.A. \& Marakas, G.M. (2010). Management Information System. $10^{\text {th }}$ Edition. McGraw-Hill/Irwin, New York.

[9] Ogedebe, P.M., \& Jacob, B.P. (2012). Software Prototyping: A Strategy to Use When User Lacks Data Processing Experience. ARPN Journal of Systems and Software, 2(6), 219-224. http://scientificjournals.org/journalofsystemsandsoftware/archive/vol2no6/vol2no6_4.pdf

[10] Purnomo, D. (2017). Model Prototyping pada Pengembangan Sistem Informasi. JIMP-Jurnal Informatika Merdeka Pasuruan, 2(2).

[11] Putro, H. P. (2014). Analisis dan Rancangan Prototipe Manajemen Dokumentasi Rekayasa Perangkat Lunak. Compiler, 3(1).

[12] Retnani, W.E.Y., \& Kristianto, W. (2016). Implementasi Prototype dalam eTourismDesa Wisata Organik Lombok Kulon. Proceeding Seminar Nasional APTIKOM 2016, 1(1), 921-925.

[13] Ulum, M. B., \& Laday, R., K. (2016). Prototype Sistem Informasi Bencana Alam. Proceeding Seminar Nasional APTIKOm 2016, 1(1), 494-497. 